\section{POPULATION GROWTH AND THE DILEMMA OF RURAL LIFE AND ECONOMY IN NIGERIA}

\section{Cornelius C. Agbodike}

\section{A. Introduction}

It is common knowledge that most Nigerians who live in the rural areas (about 75 percent of them) are, by virtue of the circumstances of their habitat, subjected to serious handicaps and constrained to scratch the earth for a rather miserable living. In fact the general impression created in the minds of most Nigerians and foreigners alike who visit our rural areas is one of total abandonment and salutary neglect of the people who inhabit these places. For most of these rural dwellers, electricity, portable water supply, clinics, heath centers and hospitals which are generally concentrated in the urban centres, are just illusive luxuries. Quite a large proportion of the rural dwellers still live in a state of nature, by-passed by the modernizing influences and forces, which revolutionize progressive modern societies. The state of the life of our rural population kills the enthusiasm of rural dwellers, dampens their morale and mitigates their sense of motivation and initiative.

The high as well as the unrestrained population growth rate of the country has, to a large extent, been blamed for this state of affairs in the rural areas. Arguments have raged between two schools of thought. One argument, presented by Clark and Ohlin, is in favour of unrestrained population growth based on the contention that it stimulates business and general economic growth cycles and therefore necessary for development ${ }^{1}$. The other argument presented by Malthus is in favour of restrained population growth on the ground that unrestrained rise in population will mean less resources for individual members leading to considerable reduction in the good life and well being of the people in that society, thus constituting an impediment to the socio-economic development of
Cornelius C. Agbodike

the society ${ }^{2}$. The practical import of these divergent views is that positively or negatively, population question is intricately related to development which by all considerations, is man-centered. Alluding to the positive and negative impact of rapid population growth, Ude asserted that "though there can be no development without human beings ... any development that does not lead to overall increase in the welfare of the people is deficient ${ }^{\prime \prime 3}$.

However, despite the merit of the arguments in favour of population growth, it is a naked truism that rapid population growth has never been an asset in tackling problems of poverty and underdevelopment, especially in a developing country like Nigeria. Therefore, Nigerians in general and the rural populace in particular, should be sensitized to the realities of their sad situation. Steps should, therefore, be taken to mobilize the energies and efforts of the people to drastically bring down and keep in check the ever increasing growth rate of the country's population and so ameliorate the unspeakable predicament of the people and accelerate the pace of the nation's rural transformation and development.

In this paper, efforts are made to discuss the issue of population growth in Nigeria in its various ramifications. In the first place, the author takes a critical look at the deplorable state of the rural communities in Nigeria. This is followed by an incisive examination of the implications of the phenomenon of population growth on the beleaguered state of these rural communities and the national economy. Specifically, the causes of population growth in Nigeria are discussed. In like manner, the implications of population growth, particularly in relation to resource consumption and sustenance of development in the country are highlighted. Next, some suggestions and recommendations are made aimed at ameliorating the dilemma of the rural communities in Nigeria, arising as a result of rapid population growth rate of the country. Finally, the author makes his concluding remarks. 


\section{B. The State of Rural Communities and Economy in Nigeria}

The plight to the rural Communities in Nigeria is the focus of current discussions by many Nigerians and a matter of concern for all levels of government in the Country. The picture of the rural countryside is described as being pathetic and the main features of the rural environment are said to be depression, degradation and deprivation ${ }^{4}$

In most rural areas in Nigeria, the basic infrastructures necessary for tolerable human existence are generally lacking. For instance, there are, in most rural communities, no functional motorable roads, thus leaving the people in those areas in dreary isolation from their neighbours elsewhere. Where roads exist atal, they are generally characterized by innumerable pot holes, deep enough to snap a car's shock absorber or give the rim a terminal damage $^{5}$. In fact the state of our rural roads is most horrible in the reverine areas with theirs marshy and difficult terrain. The sad story of our rural roads calls for great concern when it is realized that over 75 percent of Nigerians, as noted above, live in the rural areas and that it is from the latter that most of the food products of the country are derived. Without good motable roads, it becomes a big problem to send food products from these areas to the urban dwellers who mainly depend on the rural folks for their food supply. Hence, every harvest season, thousands of rural farmers watch helplessly as the crops which they cannot evacuate to the urban markets go waste, thus marginalizing their income from farm proceeds over the years.

Another common feature of rural communities in Nigeria is the deplorable lack of potable water, both for drinking and for various household chores. Some rural communities are lucky to have rivers, streams, and springs which are tolerably good for drinking and for other domestic uses. Others are not so fortunate. For some rural Nigerians, for instance, only shallow ponds may be available as source of water supply, both for man and animals. Such a source of water supply, undoubtedly, constitutes a breeding ground for such highly contagious disease carrying parasites, which cause typhoid fever, dysentery, round worms and guinea worms. In such a circumstance, therefore, people are bound to drink dirty and contaminated water.

To compound the hardship of the rural dwellers, there are hardly any good hospitals, health centers, maternity homes etc, either privately established or owned by the government to serve needs of the people. In some cases, people have to travel between 5 to 35 kilometers or more to reach the nearest health institution for treatment. Even here, many of the available health institutions lack drugs and are generally characterized by the familiar syndrome of 'O/S' (out-of-stock) in their drug dispensation. Circumstantially, therefore, the health care of such rural communities is left squarely to fate or in the hands of rural quacks and at best in the hands of traditional medicine men. In such rural communities, the muchpublicized National Programme on Immunization continues to be a mirage.

Electricity is a basic necessity which makes life for all Nigerians, including those in the rural areas, worth living. While some villages have had the privilege of being hooked on to electricity and so enjoy the benefits derived therefrom, many villages and rural communities are not so fortunate and so are denied the opportunity of enjoying the advantages of this all important commodity.

Rural communities in Nigeria suffer from other deprivations. The privilege and opportunity of acquiring functional education, for instance, which is supposed to be a birth right of every Nigerian child, become an illusion. In some places, there are no schools atal and people have to travel long distances to get to school. Where schools exist they are known to be shabby and poorly built, equipped and staffed. Many Nigerian rural communities have now struggled 
to get primary schools built in their areas, no matter how dilapidated some of them may look. This, however, cannot be said of secondary schools and technical colleges, which are totally non-existent in many rural communities or are located in places very far from some communities where they exist atal. Generally, the fees charged in these schools are high and beyond the means and reach of most of the parents in these areas. Thus, due to poverty, which is the plight of many rural parents, the latter cannot afford to give educational opportunities to their children and therefore are constrained to apprentice them to selected trades early in life.

The development and plight of rural communities are hampered in other ways, among which are the vagaries of natural disaster. In Anambra State, for example, many villages are being threatened and some have already disappeared as a result of the devastations caused by floods and associated soil and gully erosions. Presently, "over 70 percent of the land in Anambra State is being ravaged or threatened by erosion at various levels of development and over 20 percent of the land has been lost to the gullies ${ }^{6}$. These erosions are caused by natural factors like wind and intense rainfall, which generate large volumes of run-off as a result. The erosions are also caused by anthropogenic (man-made) factors acting independently or jointly with the natural causes. The man-made factors are mainly due to the very large population density in the relatively small geographical area of the state as well as the socio-economic activities of the people like deforestation, over-cropping of farm lands to feed the teeming population and clearings for infrastructural development? The areas most severely devastated by this phenomenon include Nanka, Agulu, Oko, Enugwu-Ukwu, Ekwuluobia, Oraukwu, Alor and Obosi. In all these places, arable land, houses, schools, churches, markets, shrines, crops and economic trees as well as lives and properties have been lost and are being lost to erosions.

All over our rural communities, there are eloquent testimonies and graphic picture of squalor, disease and want and of general rural neglect. In and around the villages, the distended tummies and slender legs of children, who frolick in the dust in the dreariness of their surroundings, tell part of the story. As a result of this neglect, the youths tend to migrate from the rural areas to urban centres where they hope to find and live better lives, make some achievements and be recognized. The rate of migration of able bodied young men and even some women from the rural areas to the urban centers becomes very manifest in the downward trend of the labour force in the rural areas, particularly in the area of agriculture, which moved from 67 percent in 1963 to 55 percent in $1980^{8}$.

\section{The Issue of Population Growth on the Beleaguered State of Rural Life and Economy in Nigeria}

\section{(a) The Causes of Rapid Population Growth in Nigeria}

The issue of high population growth rate is one major factor which contributes very significantly in lowering the standard of life in the rural areas and in stunting the growth of the economy. This issue brings down the rate of rural development of the country in particular and the overall development of the nation in general. The International Institute in Collaboration with National Population Bureau contends that in broad terms, well over half of the population of West Africa is in Nigeria?.

Nigeria's population increased very rapidly from 30.42 million recorded in the 1952/53 census to 55.7 million in 1963. The 1963 census figure was disputed because of alleged irregularities. Some political analysts also queried the 1963 census result and argued that an increase of almost 25 million people in 10 years meant an annual population growth rate of some 5.6 percent. This put a serious question mark on the accuracy of the head count, as that figure was unlikely in the light of the socio-economic conditions of 
that period. Be that as it may, the Federal government of the time accepted the figures and the Supreme Court of the Federal Republic of Nigeria refused to rule on the matter when the figures were challenged in the court and by so doing gave the result pseudo legal backing.

In 1973, the Gowon regime conducted another census which placed the population of Nigeria at 79.8 or approximately 80 million people. This figure did not command widespread acceptance and so was cancelled by the succeeding General Murtala Mohammed/ Olusegun Obasanjo administration which declared it a nullity and continued to use the 1963 census figures as the basis of all demographic calculations and projections in the country.

In 1980, no census could be conducted. In 1991, the then military government conducted a census. The provisional result of the 1991 census, conducted during the regime of President Ibrahim Babangida, put the population of Nigeria at $88,514,501$. The next and most recently conducted 2006 census in Nigeria put the country's population at $140,431,790$ people, comprising $71,345,488$ males and $60,086,302$ females $^{10}$. (See Extraordinary Federal Republic of Nigeria official Gazette, No.2, Vol. 96, of $2^{\text {nd }}$ February, 2009, p. B.2).

The population growth rate of the country, too, makes the population issue in Nigeria a rather disturbing question. Most of the estimates on population growth rate in Nigeria ranged between 3 to 3.5 percent. These population growth estimates were supported by Ani. Statistics from the 2006 census, whose conduct was, to a large extent, adjudged to the free and fair, indicated that the annual exponential growth rate in Nigeria, between 1991 and 206 census exercises in the country, is 3.18 percent $^{11}$. (See Extraordinary Federal Government of Nigeria Gazette, No.2, Vol. 96 of $2^{\text {nd }}$ February, 2006, p. B.2). These growth rates are relatively high when it is realized that even China, the world's most populous country, has a growth rate of about $1.3 \%$.
Various variables, including lower mortality rate resulting from advances in medical and health sciences and improvements in standard of living, relatively speaking, as well as high birth rate and the migration of foreigners into the country, account for the accelerated population growth rate in the country. There are also some cultural imperatives, which are known to loom large in influencing and creating favourable conditions for high fertility tendencies among people of various ethnic groups in Nigeria.

For example, Nigerians in general and the Igbo in particular, are traditionally known to have a culture and deep sense of love for children and large families for various socio-economic reasons. With particular reference to the Igbo, great emphasis is laid on fertility, population increase and expansion. Probably this was why Igbo land has become, in the words of Njoku, "one of the most densely peopled areas in all Africa", ${ }^{12}$ a phenomenon which antedated the establishment of colonial rule in Nigeria at the beginning of the $20^{\text {th }}$ century. Attention has also been drawn to the fact that agriculture in Nigeria has largely remained at subsistence level of hoe culture and in the hands of peasant farmers. This situation perpetuates preference for large families whose members would be used as farm hands, especially in the rural areas. And what is more, in the absence of institutionalized welfare schemes (like old peoples' homes) and with the progressive breakdown of the traditional extended family system, people tend to produce as many children as possible who will take care of them when they grow old.

The importance attached to male children in some cultural areas, especially in Igbo land leads to the phenomenon of very large families and high population growth rate. A family without a male child in Igbo traditional society is stigmatized and so easily succumbs to the temptation to try and try again to get a male child and in the process may end up raising an unwieldy family size numbering eight to ten. To this end, too, some customary practices 
even allow un-married girls or women to have children in their natal homes in order to perpetuate the family lineage.

The traditional socio-cultural practices of early marriage and polygamy still survive among many Nigerian peoples. Some diehard traditional folks even argue for its retention on the ground that it is something authentically African. The practice of polygamy, for instance, contributes to the incidence of high population growth rate in the country and so helps to compound the attendant problems resulting from it.

High population growth rate is also closely associated with ignorance and illiteracy. It is common knowledge that many rural and even urban poor have limited access to educational opportunities and are generally ignorant and illiterate. It has been estimated that "about 70 percent of Nigerians are still within illiteracy bracket"13. The fear and superstitious beliefs which ignorance generated among these Nigerians make it difficult for them to embrace certain innovations like modern methods of population control, which facilitate effective family planning. People with this type of background and mentality are very difficult to mobilize for meaningful population education and so constitute a cog in the wheel in the effort to ensure regulated family sizes and to promote sustainable development.

Certain religious beliefs and practices of the adherents of the two major religious (Christianity and Islam) in the country, tend to favour high fertility among these adherents and make them pronatalists. Among Christians, for instance, there is the Biblical injunction in Genesis $(1: 289: 1,7)$ to increase and multiply and fill the earth. In an address to the Italian Catholic Union Midwives in 1951, Pope Pius XII made it clear that it was an offence against the law of God and nature to deliberately frustrate matrimonial act in its and natural power to generate life. The same Pope also stated that "every attempt on the part of married couple during the conjugal act or during the development of its rational consequences to deprive it of its inherent power and to hinder the procreation of new life is immoral" $^{\prime 14}$. Based on these doctrines and injunctions, Catholics in Nigeria and the world over become most ardent pro-natalists. Adherents of the various Protestant denominations are also strong pro-natalists. Protestants, generally speaking, see marriage as a religious vocation and children as the gifts of God. However, the contemporary concensus of protestants on responsible parenthood holds that husband and wife are free to use the gift of science to serve the needs of that union of 'one flesh' which marriage represents, whether to facilitate conception or to limit it.

Religious beliefs and practices also play vital role in the fertility behaviour of Moslems. Prophet Mohammed, according to Fagley, was quoted as saying that "whichever soul is destined to come to this world shall come"15. With this strong sense of faith in the ethos of Islam, added Aderinto, "any question of restricting the number of offspring's tends to appear as lacking in piety"16. These practices, undoubtedly, sustain high fertility rate among the moslems.

From the foregoing references therefore, there is no gainsaying the fact that diverse factors and circumstances, particularly traditional and cultural imperatives, contribute to create conditions for the rapid growth rate of population in Nigeria. Under this situation, contends Coombs, "the labour force grows more rapidly than the economy can absorb". ${ }^{17}$ As Olusanya has conjectured, this type of situation will surely "strain our efforts at economic development", as well as impede the strive of our people, especially rural dwellers, towards the attainment of higher standards of living.

(b) The Implications of Rapid Population Growth in Nigeria The incidence of rapid population growth rate has far reaching implications and serious socio-economic consequences in the life of most Nigerians, especially those in the rural areas. 


\section{i. Economic Implications}

Economically speaking, the population growth rate of 3.18 percent per annum for the nation is said to be faster than the rate of food production and general agricultural output. This situation is further compound by the fact that there are "inequalities in access to available food supplies". ${ }^{19}$ As a result, there is serious protein, calorie and vitamin deficiency in the people's diet, leading to acute malnutrition. Odigboh, quoting UNICEF reports indicated that "half of all Nigerian children of pre-school age are now malnourished and will never reach their full potential if they survive atal". ${ }^{20}$ This is followed by a warning by the Ministry of Health, as quoted in Araka et al that "if current high levels of malnutrition persist, not only does the present generation remain at risk but the next generation of Nigerians will be intellectually deficient, thus decreasing Nigerian's chances for any long term development".21

Rapid population growth has also given rise to escalating food price inflation, which constitutes the greatest threat to the living standards of many families in Nigeria, most of whom spend some 60 percent of their earnings on food and merely exist on survival food budgets. And to paint a further gloomy picture of the food situation, a panel of physicians in Nigeria recently reported that one out of every four children, under the age of three, is suffering from stunted growth due to the escalating costs of food.

With rapid population growth rate in Nigeria, it naturally follows that increasing number of job seekers will scout for jobs in the labour market. This development becomes precarious in an economic environment like ours where job opportunities are getting slimmer and slimmer with the passage of each day. Thus, millions of our youths roam the streets and hamlets.

With the progressive and rapid population expansion in the country, the problem of dependency, resulting from the high percentage of children and the aged who live on the income of the economically active working population, is bound to grow astronomically. The dependency problem has become more burdensome, as Obikeze has observed, as "the extended family system is becoming increasingly ineffective in dealing with the problem of the ageing in Africa".22

In a country, like Nigeria, with rapid population growth rate, and families with large number of children and other dependents, the amount of savings made from earnings, if any, is drastically reduced. In such a situation, investments become depressed as not much could be dwerted from consumption expenses to ensure the capital growth and development of the country.

\section{ii. Social Implications}

Socially speaking, rapid population growth has serious implications on school enrolment and expenditure on education. With rapid rise in population, more and more children will enter school at all levels. As Coombs rightly observed "population explosion ... acted as a quantitative multiplier on the social demand (for education)".23 The Government of Nigeria, too, has stressed, as embodied in the National policy on Education, the issue of using education as an instrument, par excellence, to effect the socio-economic growth of the country and thereby ensuring faster development in the nation. ${ }^{24}$ Pushed by these driving forces, the social demand for education soars very high regardless, as Coombs observed, "of what may be happening to the economy and the resources available to education". ${ }^{25}$ As shown in Table 1 below, the primary and secondary school enrolments in the 1990s, for example, maintained a steady rise. The steady rise was, to a large extent, due to the progressively increasing growth rate of the population of the country. 


\section{TABLE 1}

Enrolment In The Primary And Secondary Schools In Nigeria 1990 - 1994

\begin{tabular}{|l|c|c|}
\hline Years & Pri. Sch. Enrolment & Sec. Sch. Enrolment \\
\hline 1990 & $13,607,249$ & $2,901,993$ \\
1991 & $13,776,854$ & $3,123,277$ \\
1992 & $14,806,035$ & $3,660,620$ \\
1993 & $15,870,280$ & $4,032,083$ \\
1994 & $16,190,947$ & $4,451,329$ \\
\hline
\end{tabular}

Source: Federal Office of Statistics (1995): Annual Abstract of Statistics.

The result of this state of affairs is that school buildings, classrooms, equipment, laboratories, books and other teaching materials, whose costs continue to rise as the Nigerian economy progressively dwindles, will be in short supply. At the same time, the services of more and more teachers would be needed and so more teachers would be recruited in our school system, resulting in astronomical rise in teachers' salaries. A gloomy picture of this state of affairs was painted in Adesina et al, where it was stated that from inspectors' reports over the years, "there is abundant evidence of inadequacies in funding, in the appropriate provision ... of school buildings and materials for instruction and under these unfortunate situations, much learning cannot be expected to occur".26

The logical outcome of the above situation is that our educational system turns out low quality products and the standard of education in most of our institutions has fallen. This development, coupled with the high un-employment rate in the country, especially among school leavers, has made education unattractive, uninspiring and rather un-rewarding. This situation, too, has led leading to the current high rate of school drop-out noted among the pupils and college students in the country, especially the male pupils and college students of Anambra State.

In the health sector, rapid population growth creates problems in the area of provision of health services, as more medical institutions, equipment, drugs, health programmes, doctors, nurses and paramedical personnel would be required. Moreover, in the face of galloping inflationary trends prevalent in the country today, health costs become very high and rise far above the reach of many Nigerians, especially the poor rural masses of our people.

And what is more, the dense population of the country, concentrated in the rural areas, tends to migrate into the urban areas in search of jobs, better life and modernization. Such continuous drift of the population from the rural areas leads to shortage of labour, particularly in agriculture, which is the mainstay of rural economy and as such constitutes the greatest problem of rural development.

\section{Recommendations to Ameliorate the Dilemma of Rural Life in Nigeria}

The successive governments in Nigeria, at their various levels, have over the years recognized the deplorable state of life among the rural Nigerian populace and have devised programmes aimed at alleviating their plight. These include: the launching of the Local Government Reforms in 1976 meant to bring Government nearer to the people at the grass root level; the establishment of river basin and rural development authorities; the attraction of World Bank assistance in executing agricultural development projects; making provisions for various welfare schemes to improve the living conditions of many Nigerians; the inauguration of various National Developments Plans; the establishment of Directorate of Food, Roads and Rural Infrastructure (DFRRI); the inauguration of National Economic Empowerment and Development Strategy (NEEDS) with its counterparts at the State and Local Government levels, viz, 
SEEDS and LEEDS respectively. All these measures are intended to "trigger off a development process that would lift the rural areas from their cataleptic depression into buoyant national economy". ${ }^{27}$ Though these programmes are seen as right steps in the right direction, they are yet to yield significant positive results. This is believed and said to be due to the steady and alarming increases in the population, which far outstrips the resources which these programmes were designed to provide.

To ameliorate the problems and dilemma of rural life and existence highlighted above, the author recommends the following measures aimed at finding lasting solutions to the issues in question. In the first place, the various tiers of Government in Nigeria should take drastic steps to enforce the provisions in the National Policy on Population (NPP), especially those which stipulate a maximum of four children per couple and encourage the establishment of family planning and fertility control centers all over the country. Nigerians should be made to realize that the issue of population control is not an impossible task. They should be made to emulate the example of countries with similar population problems like Thailand, which achieved a spectacular drop in fertility from 6 children per couple in 1960 to 3 presently and China, which slowed its population growth rate to 1.3 percent. The Government may also consider making parents who give birth to children in excess of the stipulated number in the NPP to pay exorbitant tax in respect of such extra children, as is the case in China.

Nigerians, especially the rural people, should take pains to eschew traditional and cultural bigotry in matters connected with fertility and population issues. They should be made to modernize their attitudes in such matters. This is best achieved through a programme of mass mobilization of the people. Mass mobilization here, according to Obi, is "an institutionalized enlightenment campaign and activity programme for the mobilization of all Nigerians ... for the purpose of building a great nation. It is also a campaign aimed at reversing all trends and situations including cultural practices that impede rather than promote national development and greatness". ${ }^{28}$

The best strategy for the dissemination of information on population issues is by means of population education. This approach should be made to permeate all levels and schemes of education, including adult literacy education. Through population education, of which responsible sex education is an indispensable component, ways and means of controlling births or fertility rate are explained. To this end, therefore, emphasis should be laid on the education and liberation of women from the bond of ignorance and cultural barriers, which prevent them from the role of responsible motherhood. The emphasis here on women becomes imperative because studies have shown as indicated by Isa-Mohammed, "that educated woman marries late in life, has fewer children and is more aware of the basic health and hygiene practices to ensure her family's well-being". ${ }^{29}$ Educated women are also known, according to Agbodike, "to be more receptive to family planning and control measures like the use of contraceptives and other devices ... while on the other hand, poor illiterate women find it difficult to imbibe these basic tenets of population education and control". ${ }^{30}$

The media propaganda mounted through the agency of Newspapers, radio and television gingles and slogans to educate the masses on population issues do not seem to have achieved far reaching results. For this reason, it is hereby recommended that family planning and family life education campaign should be extended to clubs, town unions, women organizations and meetings, trade unions and professional organizations and associations and the like. The propaganda here should emphasize the problems and other implications of having too many children.

Again, as the major impact of rapid population growth is felt in the area of food supply, especially by way of food shortages, there 
is the dire need to revolutionize and modernize our system of agricultural production to ensure adequate food supply for the teeming population of Nigerians and raw materials for our industries. This can be achieved through large and small-scale mechanized agriculture suited to the local situation. To this end, too, the traditional and cultural restrictions inherent in our land tenure system, which inhibit land alienation and limit farm size should be reviewed and modernized.

The adherents of the two major religious groups in Nigeria (Christianity and Islam) should learn to blend their doctrines of fertility with responsible parenthood and so should resist pressures to bring children into the world whose good life and well being cannot be guaranteed. The safe and non-controversial Billings Ovulation Method is recommended for the members of those religious organizations, which take exception to the other methods of family planning and control.

There is also a crying need by the various tiers of government in Nigeria to see that the condition of life of all Nigerians, especially those in the rural areas, is improved by the provision of basic infrastructural facilities like roads, health institutions, electricity, good and adequate water supply and the like and by the creation of opportunities for gainful employment.

The various Local Governments throughout the country have an onerous task to perform and indispensable role to play in the effort to make the life of all Nigerians, particularly those in the rural areas, less cumbersome and more wholesome that it is at present. As the third tier of Government and operating at the grass root level, they are looked upon by the rural populace to provide those essential services that give meaning to and ennoble their rural life and touch on their very existence. It is in recognition of this special role that the Federal Government reviewed upwards the fiscal and other resource allocations to the Local Government Areas in the State. The author, therefore, calls on all the treasurers, all accounting and revenue officers, internal auditors and all other officers and authorities charged with the management and disbursement of these and other allocations to the Local Government Areas to demonstrate the highest sense of responsibility and accountability in the performance of their duties and to ensure that these services are provided. They are also expected to explore various possibilities of generating funds locally, for instance, through small-scale industrial and agricultural projects and the establishment of markets. Armed with these resources, the Local Government Areas can offer revolving loans to accredited small scale rural entrepreneurs and by so doing go a long way to cushion the effect of the drudgery and ameliorate the dilemma of our rural dwellers.

\section{E. Conclusion}

It is the candid hope of the author that if the measures outlined above are painstakingly implemented, the population growth rate of Nigeria will be drastically reduced, the population itself will be brought to optimum size and aligned to match and keep pace with the available resources. It is only then that the well being of most Nigerians especially those in the rural areas can become a reality. It is also by so doing that the development of the nation, at a faster rate than it is presently, can be guaranteed. All hands should therefore be on deck to bring about the realization of this laudable national aspiration.

\section{References}

1. Clark, C. Population Growth and Land Use, New York, St. Martin's Press, 1967. See also: Ohlin, G. 'Economic Theory Confronts Population Growth' in Coale(ed) Economic Factors in Population Growth. New York, John Wiley and Sons, 1976.

2. Malthus, T.R. An Essay on the Principles of Population Harmondsworth, Penguin Books 1970. 
3. Ude, F.I.N. 'Population and Development: Issues and Problems' in Agbodike C.C. (ed) Readings in Social Sciences Awka, Mekslink Publishers (Nig) 1991.

4. Newwatch, Life in Rural Nigeria February 10, 1986, Vol. 3 No 6 p.13.

5. Ibid. P. 15

6. Egboka, B.E. (ed) The Raging War - Erosion, Gullies and Landslides Ravage Anambra State, Qek Awka, Government of Anambra State 1993, p.1.

7. Ibid, p. 64.

8. Quoted in Udoye, E.E. 'Inter-Community Cooperation and Rural Development in Nigeria' A paper presented at the Symposium organized by the School of Social Sciences, Anambra State College of Education, Awka, to mark the School of Social Sciences Week, $28^{\text {th }}-31^{\text {st }}$ May 1986. p.2.

9. International Institute in Collaboration with National Population Bureau. The Nigerian Fertility Survey 1981/82 Survey. Lagos, 1984.

10. Extraordinary Federal Republic of Nigeria official Gazette, No.2, Vol. 96 of $2^{\text {nd }}$ February, 2009, P.B2.

11. Extraordinary Federal Republic of Nigeria official Gazette, No.2, Vol. 96 of $2^{\text {nd }}$ February, 2009, P.B2.

12. Njoku O.N. 'Towards Agricultural History of West Africa: The Igbo Example' A paper presented at the History/Archaeology Departmental Seminars. (For Postgraduates) on $26^{\text {th }}$ March, 1981, University of Nigeria, Nsukka, P. 11.

13. The Standard, July 3, 1990, p. 8.

14. Address by Pope Pius XII to Italian Catholic Union Midwives, October 1951; A. AS 43, 1951.

15. Fagley, M. 'Doctrine and Attitudes of Major Religious in Regard to Fertility' in World Population Conference, Belgrade, 1965, Vol. 2. (UN, 1967) p. 82.
16. Aderinto Adeyemo. 'Religious and Education Factors in Fertility Behaviour' in IKENGA - Journal of African Studies. Vol. 4, No. 1. January 1979 Page 29.

17. Combs P.H. The World Educational Crisis - A Systems Analysis London Oxford University Press 1969 p. 88.

18. Olusanya, P.O. 'Fertility and Family Planning in Nigeria' in Proceedings No. 1 - Population Association of Nigeria (PAN) 1980, p. 327.

19. Idachaba, F.S. 'The Nature of the Nigerian Food Problem' in Journal of Agriculture, Science and Technology, Vol. 1, No. 1, University of Makurdi, June 1991, 9. 3.

20. Odigboh, E.U. 'Continuing Controversies on Tillage Mechanization in Nigeria' in Journal of Agriculture Science and Technology, Vol. 1, No. 1, June 1991. p. 46.

21. Araka J. Epheson. B, Amakoyo, S., Mukele. J., and Horst. J. (ed) 'Farmers Adjust to Economic Reforms' in African Farmer 3:5-15.

22. Obikeze, D.S. 'Socio-Economic Implications of Ageing Population Structures for Africa in the Next Two Decades' in The Nigerian Journal of Social Sciences (NJSS) Vol. 2, No 2 December 1985, Faculty of Social Sciences University of Nigeria, Nsukka. P.10.

23. Coombs, P.H. The World Educational Crisis - Systems Analysis, 1969 , p. 18.

24. National Policy on Education, 1981, Lagos, p.7

25. Coombs, P.H. The World Educational Crisis - A Systems Analysis, 1969 , p. 20.

26. Adesina, S. et al (eds) Nigerian Education, Trends and Issues, Ile Ife, University of Ife Press, Ltd., 1983 p. 19.

27. Agbodike C.C. 'Social Science and Rural Development in Nigeria: The Role of History' in M.S.O. Olisa and Johnny I Obiukwu (eds) Rural Development in Nigeria Awka Mekslink Publishers (Nig) 1992 p. 47. 
28. Obi, Lewis. 'Mamser Made Easy' in African Concord, No. 171 December 8 1987, 9. 50.

29. Isa-Mohammed, Adamu. 'Population Boom and ... Bust' in Hotline, No 21, September 1-15, 1987, p. 15.

30. Agbodike C.C. 'Culture Population and National Development The Case of Nigeria' A paper presented at the $39^{\text {th }} / 40^{\text {th }}$ Congress of the Historical Society of Nigeria held at the University of Ilorin, $24^{\text {th }}-28^{\text {th }}$ September, 1995 p.20. 